Acta Bot. Croat. 70 (1), 23-40, 2011

CODEN: ABCRA 25

ISSN 0365-0588

eISSN 1847-8476

DOI: $10.2478 / \mathrm{v} 10184-010-0003-8$

\title{
Orchid diversity of the cape of Kamenjak (Istria, Croatia)
}

\author{
Nina Vuković ${ }^{1 *}$, SLAVko Brana ${ }^{2}$, BoŽEnA Mitić $^{1}$ \\ ${ }^{1}$ Universty of Zagreb, Faculty of Science, Division of Biology, Department of Botany \\ with Botanical Garden, Marulićev trg 20, HR-10000 Zagreb, Croatia. \\ ${ }^{2}$ Natura Histrica, Obala A. Rismondo 2, HR-52210 Rovinj, Croatia.
}

Twentytwo taxa have been recorded in the south of Istrian peninsula (north Adriatic coast, Croatia). The research was performed in the period 2003-2004. A great majority of taxa belong to Euri-Mediterranean (seven taxa, 41.18\%) and Steno-Mediterranean (six taxa, $35.29 \%$ ) floral elements. Eurasiatic (two taxa, 11.76\%), Atlantic (one taxa, 5.88\%) and endemic (one taxon, 5.88\%) plants were also present. Almost a half of recorded orchids are abundant or frequent. The most of taxa are endangered s.l.; nine vulnerable (VU) plants $(52.94 \%)$, and one species endangered s.s. (EN) (5.88\%). There are also near threatened (NT) (two taxa, 11.76\%), and data deficient (DD) (one taxon, 5.88\%) plants, while others have no category assigned (four taxa, 23.53\%).

Keywords: Distribution, mapping, Orchidaceae, Istria, Croatia

\section{Introduction}

The Orchidaceae family is regarded as a delicate group of plants in Croatia - 58 taxa are included in different categories of the Red Book of Vascular Flora of Croatia (NIKOLIĆ and Topić 2005), and therefore the entire family is strictly protected by Croatian law (ANONYMOUS 2009).

According to the most recent floristic data 151 Orchidaceae taxa have been noted in Croatia (NiKOLIĆ 2009). In the literature, the presence of orchids was mostly mentioned sporadically, or in floristic papers dealing with orchid flora of certain parts of Croatia (e.g. PERKO 1998, HrŠAK et al. 1999), until the first checklist of Croatian orchids (with supplements) was completed (HRŠAK 2000, BoGDANOVIĆ 2004).

\footnotetext{
* Corresponding author, e-mail: nvukovic@lipa.botanic.hr

Copyright ${ }^{\circledR} 2011$ by Acta Botanica Croatica, the Faculty of Science, University of Zagreb. All rights reserved.
} 


\section{Materials and methods}

\section{Study area}

The researched area of Rt (Cape) Kamenjak is on the southernmost tip of Istria, the largest Croatian peninsula, northern Adriatic Sea, Croatia. Rt Kamenjak is officially known as Punta or the peninsula of Premantura (Fig. 1). It includes a $4 \mathrm{~km}$ long piece of land, extending from the village of Premantura towards the south. Many small bays and pebble beaches produce a winding coast, and the width of the peninsula varies between 600 and $1500 \mathrm{~m}$. The land is assembled of alternating valleys and hills (not higher than $50 \mathrm{~m}$ ) and extends over an area of around 400 ha, with a centroid at 44 $53^{\prime} 00^{\prime \prime} \mathrm{N}$ and $13^{\circ} 55^{\prime} 00^{\prime \prime} \mathrm{E}$. Rt Kamenjak, together with the Medulin archipelago, has been protected since 1996 due to its great floristic and landscape richness, today in the category of Important landscape named Lower Kamenjak and Medulin archipelago.

Several decades ago, before the protection, most of the population was engaged in agriculture, transforming the native vegetation Fraxino orni-Quercetum ilicis H-ić (1956) 1958 into its degradation states that nowadays prevail on Rt Kamenjak. Therefore, the original forest vegetation has finally been replaced with maquis, garrigue and dry stony grassland. There are altogether several types of vegetation occurring on Rt Kamenjak with domination of dry, eu-mediterranean grassland, and vegetation of Rt Kamenjak would be Euphorbietum nicaeensis H-ić (1956) 1958 grassland with its succession stage towards Cisto-Ericetum arboreae H-ić 1958 garrigue, Cymbopogo-Brachipodion ramosi H-ić (1956) 1958 and Vulpio-Lotion H-ić (1960) grassland, agricultural surfaces (arable land and pastures) and Pinus halepensis Mill. cultures (ŠUGAR 1977, ALEGRo 2002). Sunny and open habitats dominate throughout the landscape, making Rt Kamenjak a suitable site for many heliophilous plants, such as various orchids. Also, many other interesting plants rare in Croatia are present in this small area, such as Anthemis tomentosa L., Convolvulus linneatus L., Erodium acaule (L.) Becherer et Thell., Festuca lapidosa (Degen) Markgr.-Dann. (Topić and ŠEGUlJA 2000), as well as Cicendia filiformis (L.) Delarbre and Ophioglossum lusitanicum L. (FrEYN 1877).

Around Premantura and its surroundings the prevalent soil is eutric cambisol on Eolian deposits and relict terra rossa. Further south towards the cape the typical and shallow calcocambisol prevails (VIDAČEK 1979, ŠKORIĆ and BOGUNOVIĆ 1987).

Unfortunately, there is no meteorological station on Rt Kamenjak. According to data obtained from Pula meteorological station (about $10 \mathrm{~km}$ distant from Premantura) the climate of the wider area of Rt Kamenjak is intermediate, between semiarid and semihumid, considering the 10-year period (1994-2004) prior to the research (BERTOVIĆ 1975), and average annual precipitation is $849.7 \mathrm{~mm}$. Nevertheless, our experience during many years spent in Pula has shown that the climate of Rt Kamenjak differs from its nearest surroundings, since rainfall is often absent further south, especially during the summer months. In general, the climate of Rt Kamenjak is characterized by dry, hot summers and mild winters. Rainfall is most abundant during the autumn and winter period (September-January), while summer months July and August are the driest, sometimes with no rainfall at all. Temperatures are relatively high, with winter temperatures rarely below zero. Winter is the coldest period (December-February), and the highest temperatures appear during July and August. Rainfall data for Rt Kamenjak have been obtained for the period of 1997-1999 by TopIć 

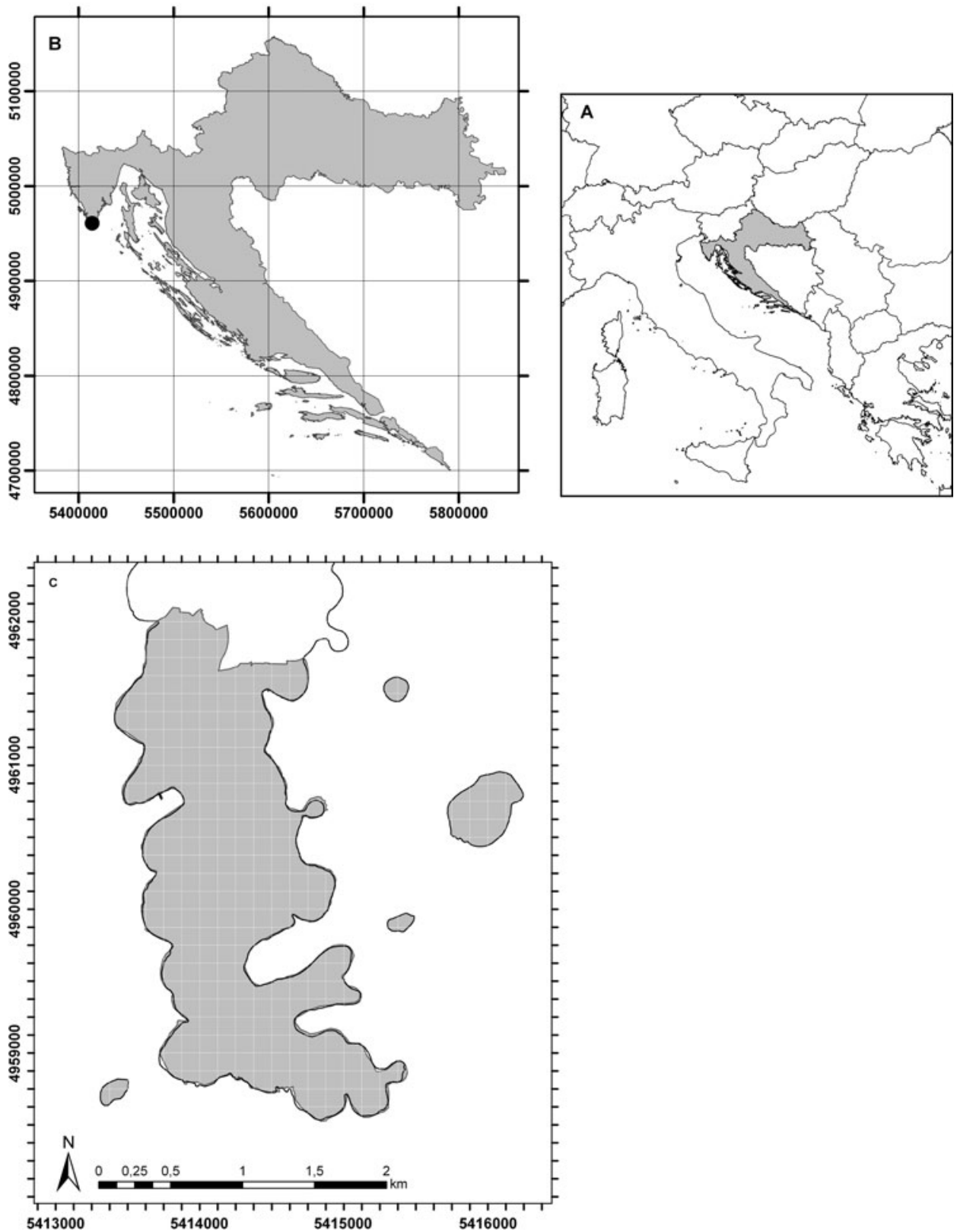

Fig. 1. Geographic position of the researched area. (A) Croatia, (B) position of Rt Kamenjak (black dot) in Gauss-Krüger grid, (C) Important landscape 'Lower Kamenjak and Medulin archipelago' (grey) with Gauss-Krüger grid subdivided into 125 x 125 m fields. 
and ŠEGULJA (2000), in order to compare the climatic aridity of Rt Kamenjak with its surroundings, Pula and Medulin. Those measurements have shown considerably less rainfall at Rt Kamenjak, particularly during summer when droughts appeared, and the authors define its climate as arid (ToPIĆ and Š́EGULJA 2000).

Twenty-three orchid taxa have been previously recorded on Rt Kamenjak (FREYN 1877; Perko 1998; STARMÜHLER 1998, 2003; TOPIĆ and ŠEGUlJa 2000; HrŠAK pers. comm.; PerČić pers. comm.). This study intends to give an updated insight of the orchid flora on »Rt Kamenjak «, and provide new information about the distribution of species throughout the area.

\section{Fieldwork}

Orchid diversity and distribution were investigated during several fieldtrips during the spring and autumn of 2003, and again in the spring of 2004, considering the usual phenology of orchids. An orthophotograph created by Geodetic Department of Rijeka supplied with Gauss-Krüger $1 \times 1 \mathrm{~km}$ grid was used as a cartographic basis for mapping. Prior to fieldwork the existing grid was divided into smaller, $125 \times 125 \mathrm{~m}$, grid fields (altogether 244 grid fields studied). The $125 \times 125 \mathrm{~m}$ grid seemed more suitable than the initially considered $100 \times 100 \mathrm{~m}$ grid, for several reasons: fieldwork is simpler with fewer fields (fewer unit surfaces and border areas among fields), it is precise enough for a qualitative study of distribution, and it was easy to draw within the existing $1000 \times 1000 \mathrm{~m}$ grid.

The entire research area was thoroughly searched several times, and the presence of orchids was entered onto the map and into the corresponding fields. This data were later used for creating digital maps of orchid distribution.

\section{Data analysis}

Identification and nomenclature of orchids followed standard determination keys and some specific scientific papers (FREYN 1877, FLEISCHMANN 1904, BAUMANN and KÜNKELE 1986, Perko 1998, Delforge 1995, Nikolić 2009), except in the case of Ophrys x sooi, for which no suitable determination literature was available at the given moment and we determined it according to its morphological resemblance to parental species.

Recorded species and subspecies are given alphabetically in the list, along with the following data: chorological type, IUCN category when applicable (EN - endangered, VU vulnerable, NT - near threatened, DD - data deficient), relative frequency ( $\mathrm{a}$ - abundant, $\mathrm{f}$ - frequent, $\mathrm{r}$ - rare, $\mathrm{rr}$ - extremely rare), number and percentage of fields containing specified taxa, flowering period (in Roman numerals corresponding to months of a year), and preferred habitats, respectively. When appropriate, some comments are given.

Chorological data were taken from PignATTI et al. (2005), and in the case of Ophrys sphegodes ssp. incubacea, Orchis coriophora ssp. fragrans and O. morio ssp. picta from DELFORGE (2006).

Abbreviations of floral elements, as defined in Pignatti (1982), are given as follows:

1. Endemic (En)

2. Steno-Mediterranean (SM)

3. Euri-Mediterranean (EM)

4. Eurasiatic (EA)

5. Atlantic (Atl.) 
IUCN categories were taken from the Red Book of Vascular Flora of Croatia (NIKOLIĆ and TopIĆ 2005).

Considering that all recorded orchids are geophytes (DELFORGE 2006), no life form was indicated.

Taxa recorded for the first time on Rt Kamenjak are marked with an exclamation mark (!). Unconfirmed taxa are marked with an asterisk (*) and later discussed. Most of the orchids recorded were photographed since no herbarium material was collected.

Hybrids are presented in a separate list, but were omitted from mapping and other analysis.

Data on the presence of orchids in different fields were used in the making of digital distribution maps of orchid taxa on Rt Kamenjak (Figs. 2 - 18) using AutoCAD R14 software (Autodesk, Inc., San Rafael, Califórnia, USA).

\section{Results}

Altogether 29 orchid taxa have been recorded on Rt Kamenjak. A total of 22 orchid taxa were noted in this survey, and previous citations mentioned seven more. Recorded species and subspecies (Tab. 1) belong to the genera Aceras (1), Anacamptis (1), Ophrys (5), Orchis (6), Serapias (3) and Spiranthes (1). Altogether five hybrids have been recorded, belonging to the following genera: Ophrys (3), Orchis (1) and Serapias (1). Findings of four species (Ophrys apifera, Orchis simia, Orchis tridentata and Serapias parviflora) and two hybrids (Ophrys x cosana and Ophrys x sooi) on Rt Kamenjak are mentioned for the first time.

\section{List of orchid species and subspecies}

Aceras anthropophorum (L.) R. Br. (Fig. 2) - Atl. - DD - (r) - 6 (2.46\%) - (IV/V). Dry grassland on calcareous ground. This taxon has been previously recorded by Perko (1998)

Anacamptis pyramidalis (L.) Rich. (Fig. 3) - EM - NT - (rr) - $1(0.41 \%)-($ V/VI). Open, dry grassland near the macadam road. Extremely rare species on Rt Kamenjak, present as a single plant. This taxon was previously recorded by PERKO (1998)

*Limodorum abortivum (L.) Sw. This taxon was previously recorded by PERčIć (pers. comm.).

!Ophrys apifera Huds. (Fig. 4) - EM - EN - (r) - $1(0.41 \%)-(\mathrm{V})$. Dry grassland surrounded with shrubs. One population of about 15-20 individuals was discovered.

*Ophrys araneola Rchb. This taxon was previously recorded by PERKO (1998).

Ophrys bertolonii Moretti (Fig. 5) - SM - VU - (a) - 76 (31.15\%) - (IV/V). Dry stony grassland and garrigue, pastures, sometimes edges of macadam and paths. This taxon was previously recorded by Perko (1998) and TOPIĆ and ŠEGUlJA (2000).

Ophrys bombyliflora Link (Fig. 6) - SM - VU - (a) - 101 (41.39\%) - (IV/V). Dense populations were found within dry grassland on calcareous ground. This taxon has been previously recorded by PERKO (1998).

Ophrys fuciflora (F. W. Schmidt) Moench (Fig. 7) - EM - VU - (r) - 10 (4.10\%) (IV/V). Grassland and open surfaces within sparse garrigue. This taxon was previously recorded by Perko (1998) (as O. holoserica) and Topić and ŠEGUlJa (2000). 
Vuković N., Brana S., Mitić B.
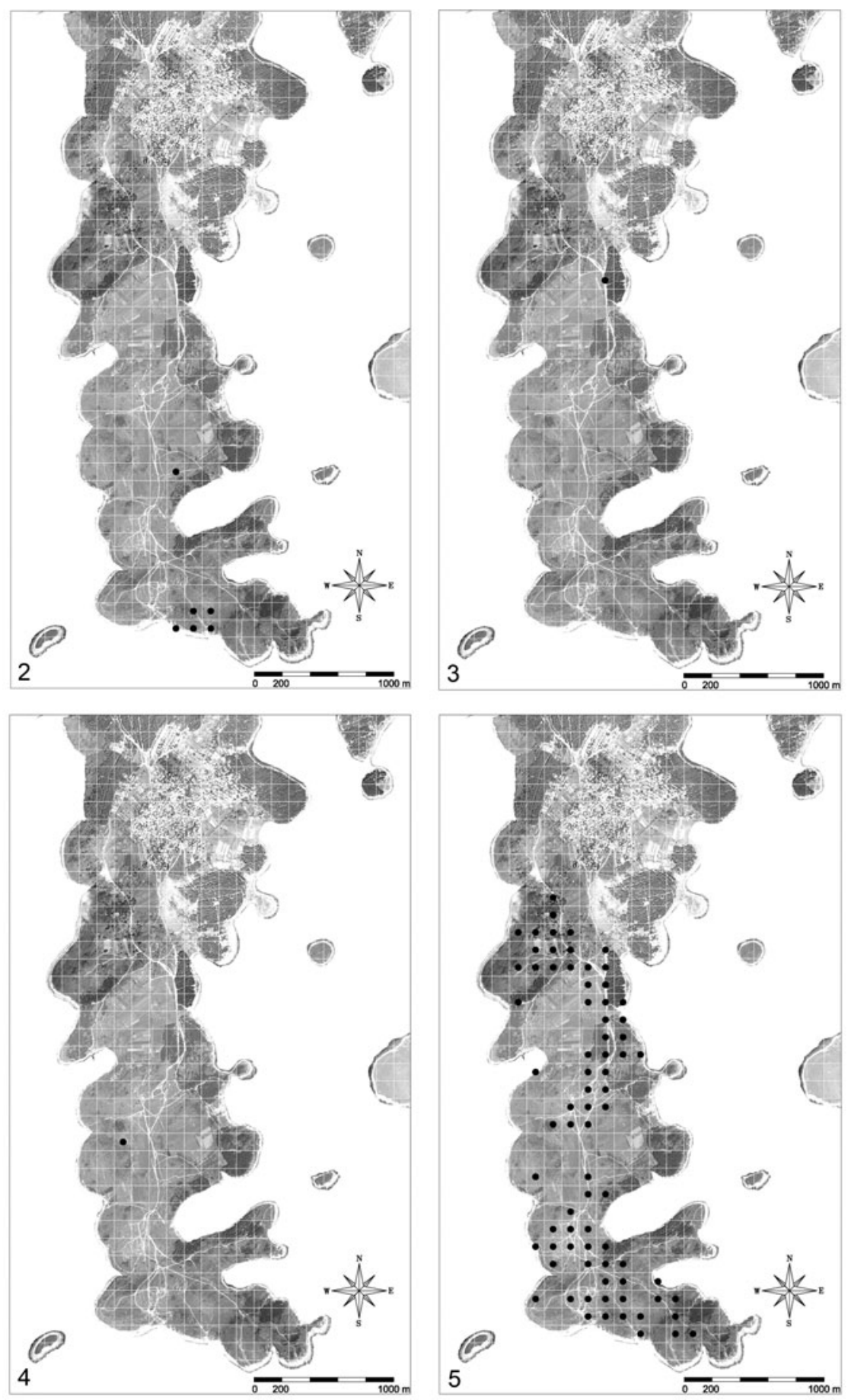

Figs. 2-5. Distribution of Aceras anthropophorum (2), Anacamptis pyramidalis (3), Ophrys apifera (4) and Ophrys bertolonii (5) on »Rt Kamenjak«. 
Ophrys sphegodes Mill. ssp. atrata (Lindl.) E. Mayer (Fig. 8) - SM - VU - (a) - 98 $(40.16 \%)-(I V / V)$. Distributed widely on grassland, garrigue, pastures and edges of macadam and paths. All records of this species belong with no exception to this subspecies.

This taxon was previously recorded by PERKO (1998) (as O. incubacea), TOPIĆ and ŠEgulJa (2000) (as O. sphegodes) and StARMUhlER (2003) (as O. incubacea).

* Ophrys sphegodes Mill. ssp. sphegodes. This taxon was previously recorded by PERKO (1998).

Orchis coriophora L. ssp. fragrans (Pollini) Sudre (Fig. 9) - EM - VU - (r) - 5 (2.05\%) - (V/VI). Grassy surfaces along macadam roads. This taxon was previously recorded by PERKO (1998).

Orchis morio L. ssp. picta (Loisel.) K. Richter (Fig. 10) - SM - NT - (a) - 138 $(56.56 \%)-(\mathrm{IV} / \mathrm{V})$. Very widespread taxon found almost everywhere, on dry grassland, garrigue, pastures, along macadam and paths, edges of abandoned agricultural land and olive groves. This taxon was previously recorded by PERKO (1998) and TopIĆ and ŠEGULJA (2000) (as O. morio).

Orchis papilionacea L. (Fig. 11) - EM - VU - (a) - 141 (57.79\%) - (IV/V). Very abundant species found in most habitats: dry grassland, garrigue, pastures, edges of macadam and paths and sometimes on abandoned agricultural land and olive groves. This taxon was previously recorded by TOPIĆ and ŠEGULJA (2000).

*Orchis papilionacea L. ssp. rubra (Jacquin) H. Sund. This taxon was previously recorded by PERKO (1998).

* Orchis provincionalis Balb. ssp. pauciflora (Ten.) E. G. Camus. This taxon was previously recorded by FREYN (1877), and TOPIĆ and ŠEGULJA (2000) (unconfirmed).

Orchis purpurea Huds. (Fig. 12) - EA - VU - (rr) - 1 (0.41\%) - (IV). Edge of maquis along roadside. Extremely rare species on Rt Kamenjak, presented with a single plant. This taxon was previously recorded by PERKO (1998).

!Orchis simia Lam. (Fig. 13) - EM - VU - (rr) - 1 (0.41\%) - (IV/V). Grassy surface in the vicinity of garrigue. This species was presented with a small group of individuals in one field.

!Orchis tridentata Scop. (Fig. 14) - EM - VU - (rr) - 3 (1.23\%) - (IV/V). Grassland and grassy surfaces surrounded by garrigue. This species has been found in several locations but only a single plant per field.

*Serapias cordigera L. This taxon was previously recorded by ToPIć and ŠEGULJA (2000) and HRŠAK (pers. comm.).

Serapias istriaca Perko (Fig. 15) - En (Istria) - (f) - 71 (29.10\%) - (V/VI). Dry, calcareous grassland. Distributed on the southern part of the investigated area, occasionally found quite close to seashore. This taxon was previously recorded by PERKO (1998) and STARMUHLER (2003).

Serapias lingua L. (Fig. 16) - SM - (a) - 163 (66.80\%) - (IV/V). Extremely abundant species, found in almost every habitat: dry and stony grassland, garrigue, pastures, edges of macadam and paths, abandoned olive groves, edges of agricultural surfaces. It is the second most widespread species on Rt Kamenjak. This taxon was previously recorded by PERKO (1998), Topić and ŠEGUlJA (2000) and STARMUHLER (2003). 
Vuković N., Brana S., Mitić B.
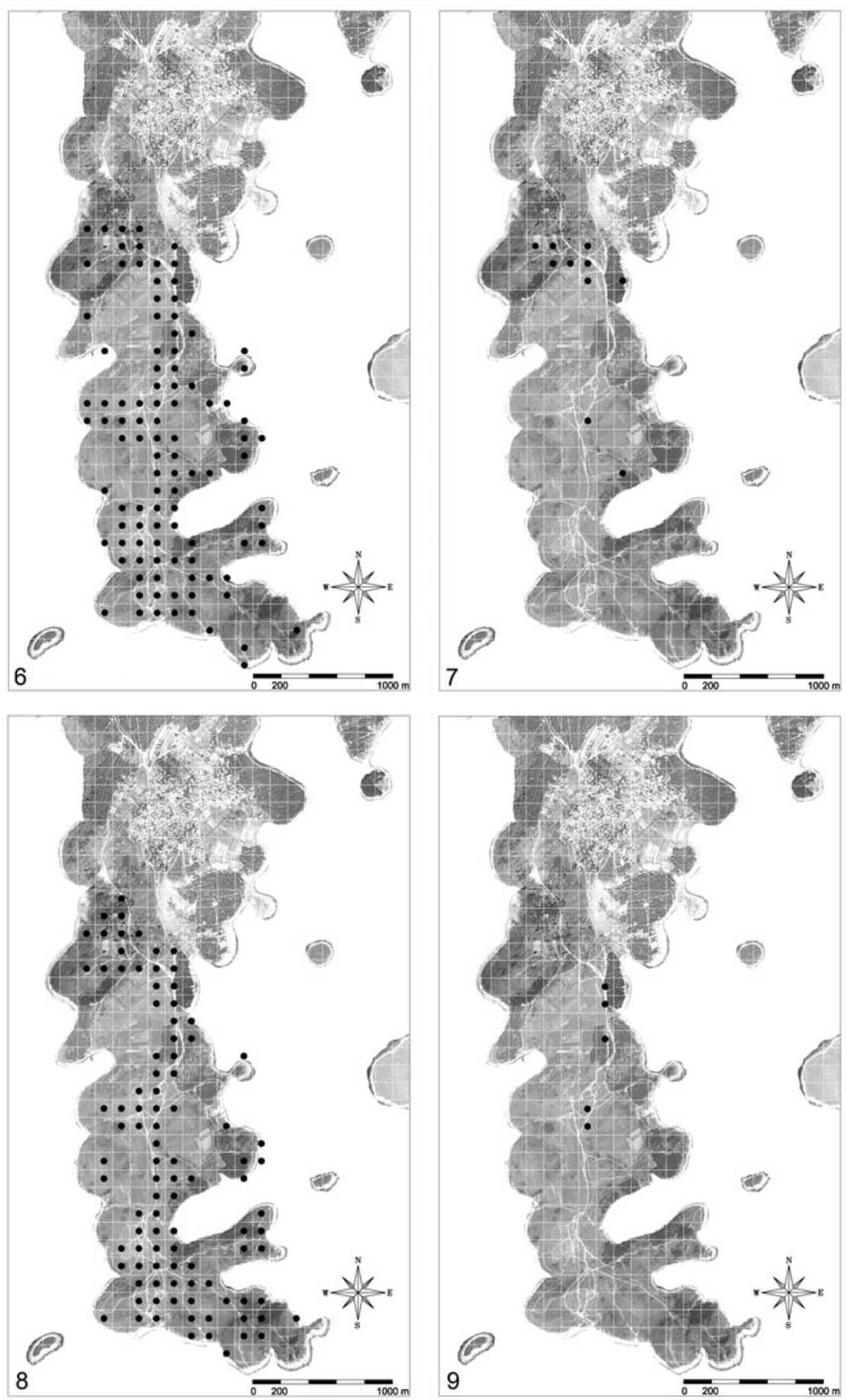

Figs. 6-9. Distribution of Ophrys bombyliflora (6), Ophrys fuciflora (7), Ophrys sphegodes ssp. atrata (8) and Orchis coriophora ssp. fragrans (9) on »Rt Kamenjak 
ORCHIDS IN ISTRIA (CROATIA)
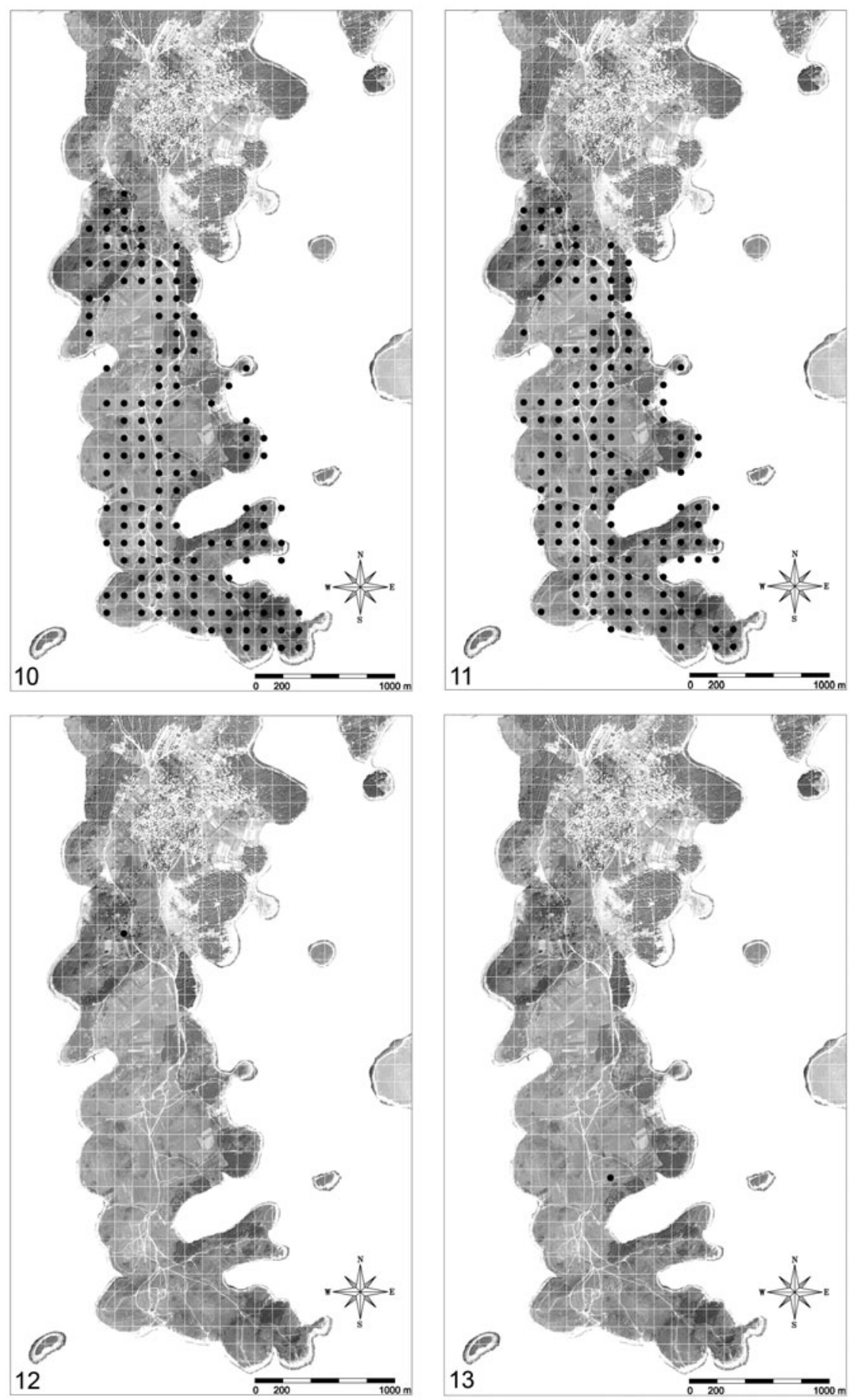

Figs. 10-13. Distribution of Orchis morio ssp. picta (10), Orchis papilionacea (11), Orchis purpurea (12) and Orchis simia (13) on »Rt Kamenjak «. 
Vuković N., Brana S., Mitić B.
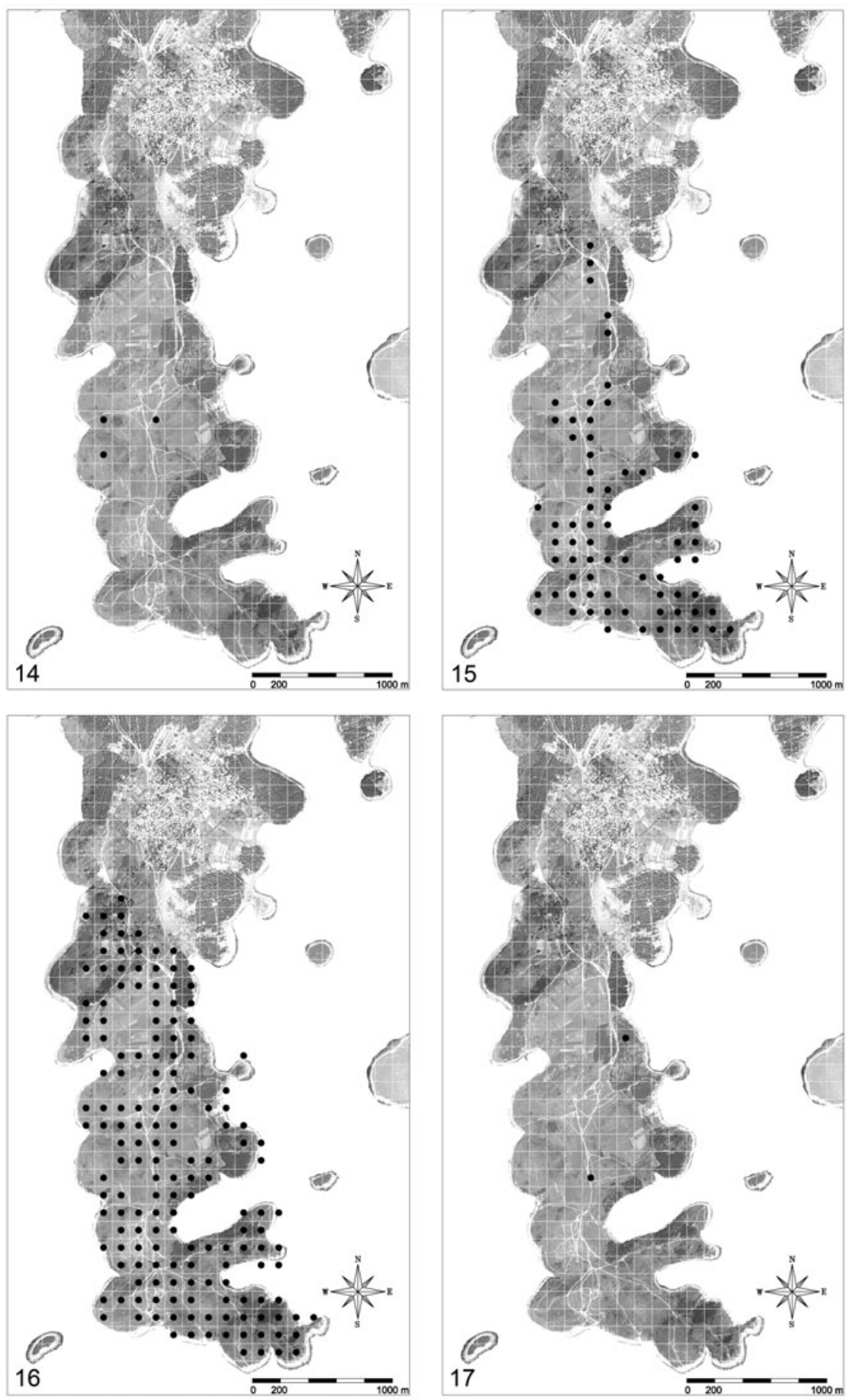

Figs. 14-17. Distribution of Orchis tridentata (14), Serapias istriaca (15), Serapias lingua (16) and Serapias parviflora (17) on »Rt Kamenjak«. 
!Serapias parviflora Parl. (Fig. 17) - SM - (rr) - 2 (0.82\%) - (V). Dry grassland near the macadam. Findings of this species included only two single plants recorded in different fields.

*Serapias vomeracea (Burm.) Briq. This taxon was previously recorded by Topić and ŠEgulJa (2000).

Spiranthes spiralis (L.) Chevall. (Fig. 18) - EA - (a) - 179 (73.36\%) - (IX/X). Extremely abundant species found on dry and stony grassland, garrigue, edges of macadam, paths and maquis, in olive groves, on pastures and abandoned agricultural land. The distribution maps show that this is the most widespread species on Rt Kamenjak, occasionally found very close to the seashore, sometimes even at the edge of vegetation towards the sea. This taxon was previously recorded by PERKo (1998), Topić and ŠEGULJA (2000) and STARMUHLER (1999).

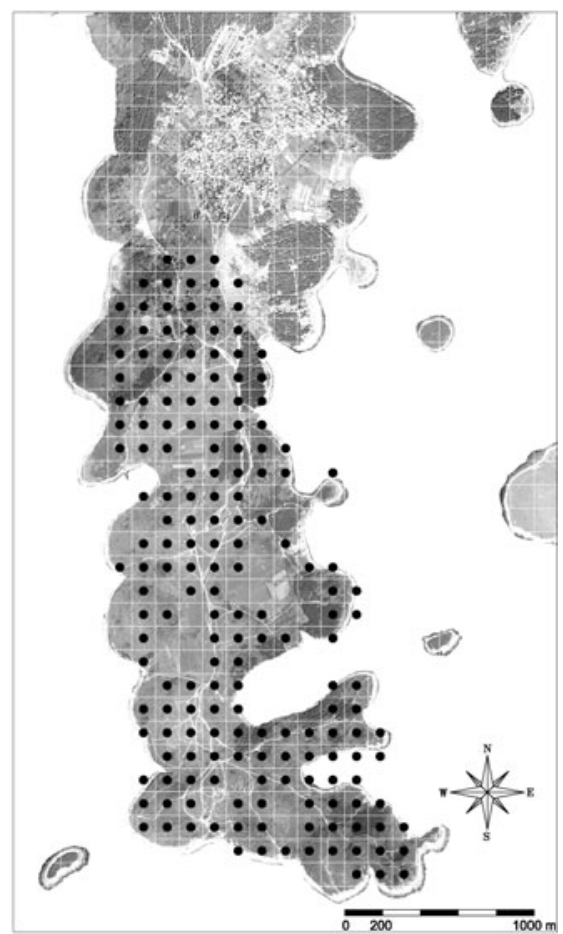

Fig. 18. Distribution of Spiranthes spiralis on »Rt Kamenjak«.

\section{List of orchid hybrids}

!Ophrys x cosana H. Baumann et Künkele (=Ophrys sphegodes Mill. ssp. atrata (Lindl.) E. Mayer x Ophrys bombyliflora Link). One individual plant was found on dry pasture near the macadam. High abundance of parental species was detected in the immediate vicinity. 
Ophrys x lyrata H. Fleischm. (=Ophrys sphegodes Mill. ssp. atrata (Lindl.) E. Mayer X Ophrys bertolonii Moretti). This taxon was quite widely distributed in the investigated area, occurring on almost every site along with the parental species. This hybrid was previously recorded by PERKO (1998).

!Ophrys x sooi A. Fuchs (=Ophrys sphegodes Mill. ssp. atrata (Lindl.) E. Mayer x Ophrys fuciflora (F. W. Schmidt) Moench). Several plants were found on a dry grassy surface along a macadam road.

Orchis x gennarii Rchb. f. (=Orchis morio L. ssp. picta (Loisel.) K. Richter x Orchis papilionacea $\mathrm{L}$.). The taxon is very widespread, occurring in most habitats along with its parental species. This hybrid was previously recorded by PERKO (1998).

Serapias x pulae Perko (=Serapias istriaca Perko x Serapias lingua L.). Endemic taxon. Only several plants were recorded. This hybrid was previously recorded by PERKO (1998).

\section{Floristic analysis}

Chorological spectrum of the orchids noticed in this research (Tab. 1., Fig. 19) shows that a total of 13 species and subspecies $(76.47 \%)$, belong to the Mediterranean group of plants, with Euri-Mediterranean (seven taxa, 41.18\%) and Steno-Mediterranean (six taxa, $35.29 \%$ ) geoelements. Other geoelements were Eurasiatic (two taxa, 11.76\%), Atlantic (one taxa, 5.88\%), and endemic (Serapias istriaca endemic for Istria, 5.88\%).

Tab. 1. Threat level, flowering period and floral element of Orchidaceae species and subspecies recorded on »Rt Kamenjak«.

\begin{tabular}{lccc}
\hline Taxa & Threat level & Flowering period & Floral element \\
\hline Aceras anthropophorum & DD & IV-V & Atl. \\
Anacamptis pyramidalis & NT & V-VI & EM \\
Ophrys apifera & EN & V & EM \\
Ophrys bertolonii & VU & IV-V & SM \\
Ophrys bombyliflora & VU & IV-V & SM \\
Ophrys fuciflora & VU & IV-V & EM \\
Ophrys sphegodes ssp. atrata & VU & IV-V & SM \\
Orchis coriophora ssp. fragrans & VU & V-VI & EM \\
Orchis morio ssp. picta & NT & IV-V & SM \\
Orchis papilionacea & VU & IV-V & EM \\
Orchis purpurea & VU & IV & EA \\
Orchis simia & VU & IV-V & EM \\
Orchis tridentata & VU & IV-V & EM \\
Serapias istriaca & - & V-VI & En (Istria) \\
Serapias lingua & - & IV-V & SM \\
Serapias parviflora & - & V & SM \\
Spiranthes spiralis & - & IX-X & EC \\
\hline
\end{tabular}




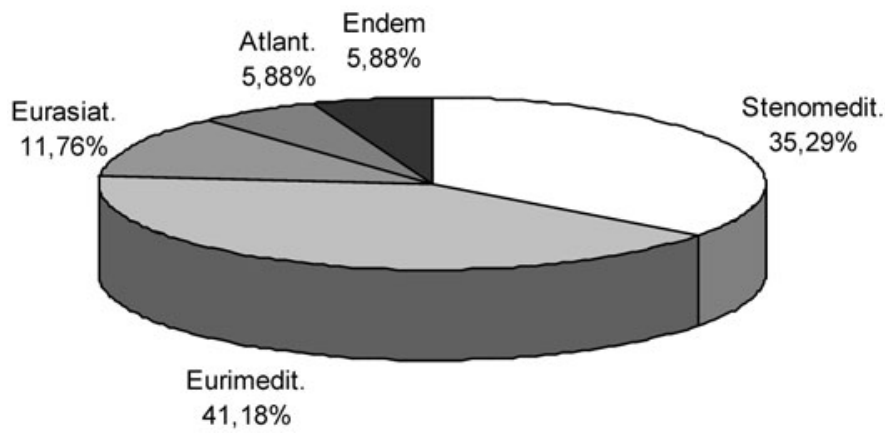

Fig. 19. Chorological spectrum of orchid species and subspecies recorded on »Rt Kamenjak«.

Analysis of endangered taxa (Tab. 1, Fig. 20) shows that one species Ophrys apifera is endangered (EN - 5.88\%), nine $(52.94 \%)$ are vulnerable (VU), two $(11.76 \%)$ are near threatened (NT) and one (5.88\%) is data deficient (DD), while four taxa (23.53\%) have not been assigned an IUCN category.

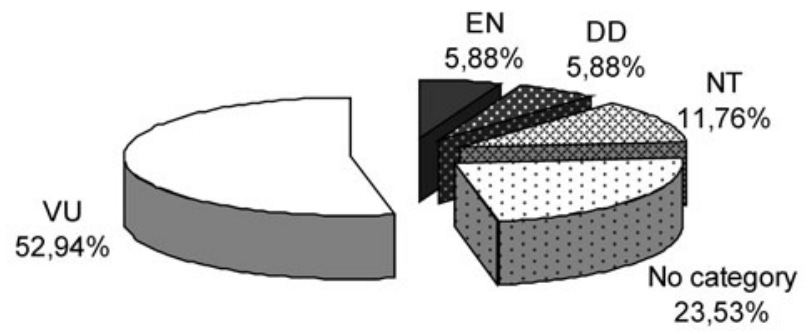

Fig. 20. Threat level of orchid species and subspecies recorded on »Rt Kamenjak«.

Relative frequency of orchid species and subspecies on Rt Kamenjak is shown on figure 21 , and also in table 2, which shows that they can be grouped, almost equally, into two groups based on their abundance (1) abundant/frequent and (2) rare/extremely rare species.

The distribution of all species and subspecies recorded in this survey is presented with distribution maps (Figs. 2-18). The most widespread species is Spiranthes spiralis re-

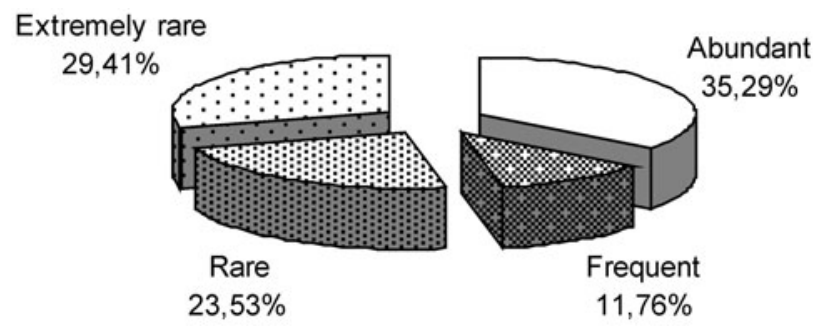

Fig. 21. Relative frequency of orchid species and subspecies recorded on »Rt Kamenjak«. 
Tab. 2. Abundance of Orchidaceae species and subspecies recorded on »Rt Kamenjak « (Total number of surveyed fields: 244). Fields (No.) - number of fields containing the taxa, Fields (\%) percentage of fields containing the taxa, Rel. freq. - relative frequency of the taxa.

\begin{tabular}{lccc}
\hline Taxa & Fields (No.) & Fields $(\%)$ & Rel. freq. \\
\hline Spiranthes spiralis & 179 & 73,36 & $\mathrm{a}$ \\
Serapias lingua & 163 & 66,80 & $\mathrm{a}$ \\
Orchis papilionacea & 141 & 57,79 & $\mathrm{a}$ \\
Orchis morio ssp. picta & 138 & 56,56 & $\mathrm{a}$ \\
Ophrys bombyliflora & 101 & 41,39 & $\mathrm{a}$ \\
Ophrys sphegodes ssp. atrata & 98 & 40,16 & $\mathrm{a}$ \\
Ophrys bertolonii & 76 & 31,15 & $\mathrm{f}$ \\
Serapias istriaca & 71 & 29,10 & $\mathrm{f}$ \\
\hline Ophrys fuciflora & 10 & 4,10 & $\mathrm{r}$ \\
Aceras anthropophorum & 6 & 2,46 & $\mathrm{r}$ \\
Orchis coriophora ssp. fragrans & 5 & 2,05 & $\mathrm{r}$ \\
Ophrys apifera & 1 & 0,41 & $\mathrm{r}$ \\
Orchis tridentata & 3 & 1,23 & $\mathrm{rr}$ \\
Serapias parviflora & 2 & 0,82 & $\mathrm{rr}$ \\
Orchis simia & 1 & 0,41 & $\mathrm{rr}$ \\
Anacamptis pyramidalis & 1 & 0,41 & $\mathrm{rr}$ \\
Orchis purpurea & 1 & 0,41 & $\mathrm{rr}$ \\
\hline
\end{tabular}

corded in 179 fields (Fig. 18), followed by Serapias lingua recorded in 163 fields (Fig. 16). The extremely rare species are Anacamptis pyramidalis (Fig. 3) and Orchis purpurea (Fig. 12), each represented with a single individual.

Most of the orchids recorded in this study (16 taxa, 94.12\%) flowered during spring, with Ophrys bombyliflora and Orchis morio ssp. picta in middle April as the earliest, and

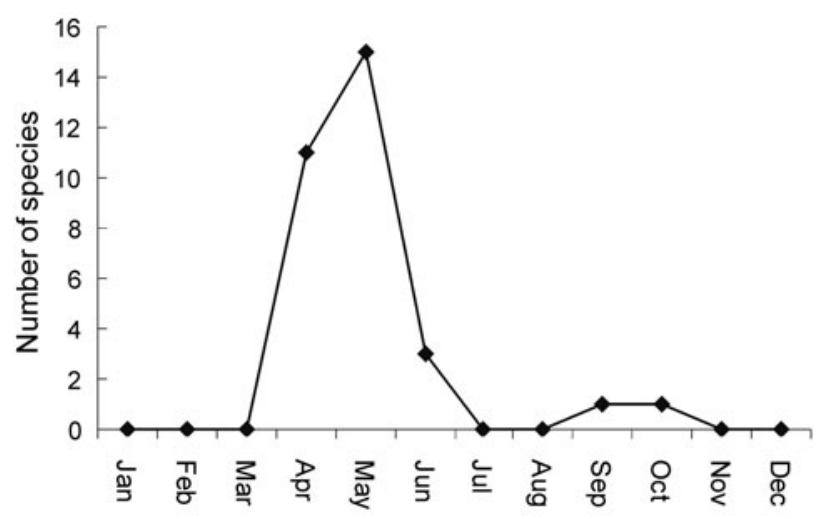

Fig. 22. Number of orchid species and subspecies recorded on Rt Kamenjak flowering in different periods of the year. 
Serapias istriaca in late May as the latest spring flowering orchid. Only Spiranthes spiralis flowered in autumn (September-October) (Tab 1, Fig. 22).

\section{Discussion}

This research has failed to confirm previous findings of some orchid species and subspecies:

Serapias cordigera was previously recorded by ToPIĆ and ŠEGULJA (2000) and HRŠAK (pers. comm.), who found only one small population of $S$. cordigera, on a single locality. Perhaps due to its localized occurrence the species was not confirmed during our survey.

Ophrys araneola was previously noted only by PERKO (1998). Orchis provincionalis ssp. pauciflora was first noted by FREYN (1877), with ToPIĆ and ŠEGULJA (2000) quoting those findings in their paper without confirmation. In the case of Ophrys sphegodes, our records belong without exception to the subspecies atrata, but the typical subspecies has been noted by PERKo (1998). Records of O. sphegodes in TOPIĆ and ŠEGULJA (2000) probably refer to the subspecies atrata, since it has shown to be rather abundant on Rt Kamenjak. There is a possibility that those taxa (Ophrys araneola, Orchis provincionalis ssp. pauciflora and Ophrys sphegodes ssp. sphegodes) are also present but rare on Rt Kamenjak, and their individual or scarce appearance is the reason for their being overlooked. On the other hand, there is a possibility that some species are extinct on Rt Kamenjak. For example, a few individuals of Limodorum abortivum were noticed a few years prior to the research at a single locality (PERČIĆ pers. comm.), but since then there has been no trace of those individuals. It should also be taken into consideration that seasonal and annual variations of the climatic conditions could be associated with annual changes in emergence and flowering of some species (TYLER 2001, COATES et al. 2006). Thus, it is possible for a species to be observed one year and not the other, but still be present on the site.

The single appearance of Orchis purpurea could be explained with the absence of some habitats like woodland edges and open woodland (the only plant was found on a shady spot at the edge of dense maquis). However, there is no obvious reason for the limited appearance of some species, such as Anacamptis pyramidalis, since dry, calcareous Mediterranean grasslands that cover most of Rt Kamenjak are common habitats for this species.

Several small groups of plants recorded in a few fields were identified as Ophrys fuciflora, known as a very variable and polymorphic species (DELFORGE 1995) with many described subspecies, varieties and forms. The relations within $O$. fuciflora group are still rather unclear, as a result of various approaches to complex and different interpretations among different authors. Thus, some authors state the possibility that the medio-European O. fuciflora does not occur south of the Central Massif and the Alps, but it is replaced by a number of locally distributed endemic populations (DELFORGE 2006), such as Istrio-Quarnerian Ophrys untchjii (DEVILLERS and DeVILLERS-Terschuren 2004). Ophrys untchjii (sometimes referred to as $O$. fuciflora var. untchjii) has a locus classicus in Istria and seems to be endemic for Croatia (DELFORGE 2006).

Serapias vomeracea was previously recorded by Topić and ŠEgulJA (2000). The species is similar to the endemic $S$. istriaca, and a certain possibility of confusion between the two species exists (Perko 1998). Given the fact that fieldwork by ToPIĆ and ŠEGUlJA (2000) was carried out before $S$. istriaca was described, this record probably refers to $S$. istriaca. 
Previous notation of Orchis papilionacea as subspecies rubra mentioned by PERKO (1998) was not confirmed in this research, probably because the plant identification, in this case, did not go further than the species level.

Records of Ophrys apifera on Rt Kamenjak are given here for the first time, although there are some dubious earlier citations of this species. Ophrys holoserica is listed in the orchid flora of Rt Kamenjak (PERKo 1998), but it remains unclear whether the name refers to $O$. apifera or $O$. fuciflora. Our research has shown that $O$. apifera has a very limited area of distribution on Rt Kamenjak and $O$. fuciflora is somewhat more widely distributed, so it is more likely that the above-mentioned name refers to the latter.

Orchis simia was presented with a small group of individuals in one field, and findings of Orchis tridentata and Serapias parviflora included only a few plants recorded in different fields and thus they were probably overlooked by other authors, due to their extremely rare appearance on Rt Kamenjak. Distribution of those, as well as other rare orchid taxa on Rt Kamenjak, should be investigated more closely.

The two most widespread species on »Rt Kamenjak«, Spiranthes spiralis and Serapias lingua, and also some other very abundant taxa like Orchis morio ssp. picta and Orchis papilionacea, are affiliated with a wide range of habitats, which seems to be responsible for such a wide distribution.

It was often difficult to determine whether a certain individual is a parental species or a hybrid, due to a great variability of parental plants and many intermediate forms towards hybrids. Similarity to the parent Serapias lingua is probably the reason why only a few individuals of the endemic Serapias x pulae were recorded. Several plants found on dry grassy surface along macadam road were named Ophrys x sooi, due to their morphological resemblance to both parental species, and also to the fact that parents were detected on the same locality. However, those findings should be investigated more thoroughly and further confirmation of this record is needed. It is the same in the case of Ophrys x cosana, since only one plant was found in the surveyed area (surrounded with abundant populations of both parental species).

Our study has shown that Serapias lingua, S. istriaca and Spiranthes spiralis often inhabit areas in the near vicinity of the seashore; therefore those species probably have greater tolerance to salinity.

Since the investigated area is situated on the very coast of the Eastern Adriatic, a high number of Mediterranean species was expected (TopIĆ and ŠEGULJA 2000), a hypothesis borne out by our data.

The size of the 125 x $125 \mathrm{~m}$ basic grid unit proved to be appropriate for acquiring precise and authentic distribution maps and could be applied in the mapping of other flora on $»$ Rt Kamenjak «.

We can conclude that Rt Kamenjak can be regarded as a remarkable orchid site since it contains at least 22 out of 151 Croatian orchid taxa, while its area of $4 \mathrm{~km}^{2}$ is rather small in comparison with the $56,600 \mathrm{~km}^{2}$ area of Croatia. Moreover, Rt Kamenjak is characterised with large populations of some widely distributed taxa, as well as with an established population of the endemic Serapias istriaca. The rich and diverse orchid flora of Rt Kamenjak makes this area a significant orchid site in Croatia. As many as $58.82 \%$ of the orchids of Rt Kamenjak have the status of vulnerable and endangered species; this increases the floristic 
importance of this orchid resort. The high number of threatened and endemic taxa and also the fact that Croatian law strictly protects the Orchidaceae family indicate that greater efforts should be made to preserve this site, perhaps by assigning it a higher level of protection. In order to expand the knowledge about plant distribution and improve the conservation of this Important landscape, we highly recommend mapping in high resolution for other plant species of Rt Kamenjak, especially for rare, endemic and endangered plants.

\section{Acknowledgments}

The authors would like to thank Mladen Perčić from the Public Institution Natura Histrica for providing transport and sharing his orientation ability during numerous fieldtrips. Special thanks go to Andrej Stroj, Igor Boršić and Maja Hlastec Bišćan for their help in the making of digital maps. We are also grateful to our colleague Sandro Bogdanović for helpful suggestions and critical comments on the manuscript.

\section{References}

Alegro, A. L., 2002: Morphometric, ecological and phytosociological characteristics of species from the genus Festuca L. (Poaceae) on the grasslands of Istria (in Croatian). MSc Thesis, University of Zagreb.

ANONYMOUS 2009: Ordinance on designating wild taxa protected and strictly protected (in Croatian). Narodne Novine 99/09.

Baumann, H., KünKEle, S. 1986: Die Gattung Ophrys L. - eine taxonomische Übersicht. Mitteilungen des Arbeitskreises »Heimische Orchideen« Baden-Württemberg 18, 305688.

BERTOvić, S., 1975: Contribution to understanding relations among climate and vegetation in Croatia. Period 1948-1960 (in Croatian). Prirodoslovna istraživanja 41, Acta Biologica 7, 89-215.

Bogdanović, S., 2004: Orchidaceae. In: Bogdanović, S., Nikolić, T. (ed.), Notulae ad indicem florae Croaticae 4. Natura Croatica 13, 416-417.

Coates, F., Lunt, I. D., Tremblay, R. L., 2006: Effects of disturbance on population dynamics of the threatened orchid Prasophyllum correctum D. L. Jones and implications for grassland management in south-eastern Australia. Biological Conservation 129, 59-69.

Delforge, P., 1995: Orchids of Britain and Europe. Harper Collins Publisher, London.

Delforge, P., 2006: Orchids of Europe, North Africa and the Middle East. Timber Press, Portland.

Devillers, P., Devillers-Terschuren, J., 2004: Small-flowered Ophrys of the Ophrys fuciflora complex in the northern Adriatic and its approaches. Naturalistes Belges 85 (Orchidaceae 17), 39-48.

FleischmanN, H., 1904: Zur Orchideen-Flora Lussins. Verhandlungen der ZoologischBotanischen Gesellschaft in Wien 54, 471-477.

FreYN, J., 1877: Die Flora von Süd Istrien. Verhandlungen der Zoologisch-Botanischen Gesellschaft in Wien 27, 241-490. 
HRŠAK, V., 2000: Orchidaceae. In: Nikolić, T. (ed.), Index Florae Croaticae, 3. Natura Croatica 9, Supplement 1, 163-173.

Hršak, V., Nikolić, T., Plazibat, M., Jelaska, S. D., Bukovec, D., 1999: Orchids of Medvednica Natural Park, Croatia. Acta Biologica Slovenica 42, 13-37.

Nikolić, T., Topić, J. (eds.), 2005: Red Book of vascular flora of Croatia (in Croatian). Ministarstvo kulture, Državni zavod za zaštitu prirode, Zagreb.

Nikolić, T. (ed.), 2009: Flora Croatica Database. [URL: (21.10.2009.)]. Department of Botany, Faculty of Science, University of Zagreb.

Perko, M. L., 1998: Ergänzungen zur Flora von Istrien (Kroatien/Hrvatska): Serapias istriaca M. L. Perko, spec. nov. und Serapias x pulae M. L. Perko, nothospec. nov. (Orchidaceae). Berichte aus den Arbeitskreisen Heimische Orchideen 15, 13-27.

PignatTi, S., 1982: Flora d'Italia 1, 3. Edagricole, Bologna.

Pignatti, S., Menegoni, P., Pietrosanti S. 2005: Valori di bioindicazione delle piante vascolari della Flora d'Italia. Bioindicator values of vascular plants of the Flora of Italy. Braun-Blanquetia 39, 3-95.

STARMÜHLER, W., 1998: Vorarbeiten zu einer »Flora von Istrien«, 2. Carinthia 2 189/109, 431-466.

STARMÜHLER, W., 2003: Vorarbeiten zu einer »Flora von Istrien«, 6. Carinthia 2 193/113, $579-658$.

ŠKorić, A., Bogunović, M., 1987: Geography of soils. In: ŠKorić, A. (ed.), Pedosphere of Istria (with pedological map) (in Croatian). Projektni savjet pedološke karte Hrvatske, Posebna izdanja, knjiga 2. Zagreb.

ŠugAR, I. (ed.), 1977: Vegetation map of Croatia, section Pula (in Croatian). Institute for Botany, University of Zagreb.

Topić, J., ŠEgUlJa, N., 2000: Floristic and ecological characteristics of the southernmost part of Istria (Croatia). Acta Botanica Croatica 59, 179-200.

TyLER, G., 2001: Relationships between climate and flowering of eight herbs in a Swedish deciduous forest. Annals of Botany 87, 623-630.

VIDAČEK, Ž., 1979: Basic pedological map of section Pula 1, scale 1:50 000 (in Croatian). Projektni savjet za izradu pedološke karte SR Hrvatske, Zagreb. 